\title{
Training on the Utilization of Household Organic Waste as Compost Fertilizer in Tamansuruh Village
}

\author{
Jefry Aulia Martha', Mohammad Hilfi Azra Dzikrulloh², Reta Lola Oftaviana ${ }^{3}$, Hafifatus Syabila ${ }^{4}$ \\ 1,2,3,4State University of Malang \\ Email: jefry.aulia.fe@um.ac.id \\ doi https://doi.org/10.36526/gandrung.v2i2.1382
}

\begin{abstract}
Problems related to waste, waste processing, to environmental pollution will become a big problem if not handled properly. These problems can be solved with economical solutions such as the utilization of household organic waste into compost. This program aims to help the community to be able to produce compost from household organic waste in Tamansuruh Village, which is one of the villages in Glagah District, Banyuwangi Regency. Where the problems faced by the villagers are the lack of information and limited knowledge about new innovations in making compost. The process used in this composting is anaerobically assisted by a simple composter. To achieve this goal, the method used is preparation in the form of observation of problems, implementation in the form of socialization, training, and direct practice, and evaluation. The result of this activity is in the form of compost derived from household organic waste made by residents and for the residents themselves. Making compost is also able to increase the innovation power of residents in managing household organic waste and increase productivity in the field of agriculture.
\end{abstract}

Keyword: Organic Waste, Compost, Composter, Anaerobically

\section{Pendahuluan}

Tamansuruh merupakan salah satu desa di Kecamatan Glagah, Kabupaten Banyuwangi. Luas Desa Tamansuruh sendiri sekitar 10,47 $\mathrm{km}^{2}$ yang terdiri dari 5 dusun yaitu Dusun Wonosari, Dusun Andong, Dusun Krajan, dan Dusun Mondoluko. Desa Tamansuruh ini terdiri dari berbagai persawahan, perkebunan sayur, hingga terdapat berbagai tempat wisata. Mayoritas penduduk Desa Tamansuruh bekerja sebagai petani maupun buruh tani. Hal ini menyebabkan di desa tersebut banyak sekali limbah-limbah terutama limbah organik yang berasal dari hasil tani maupun rumah tangga. Hadiwiyono (1983) dalam bukunya juga menyebutkan bahwa komponen limbah terbesar di Indonesia dan mencapai $80-90 \%$ ialah limbah organik. Limbah organik sendiri merupakan limbah yang sebagian besar tersusun oleh senyawa organik yang ada dalam sisa tanaman, hewan atau kotoran (Nur et al., 2018). Walaupun limbah ini dapat terurai secara alami, akan tetapi bila dibiarkan begitu saja akan menimbulkan sumber penyakit dan bau yang tidak sedap. Selain itu, terdapat juga anggapan bahwa mengelola sampah organik membutuhkan lahan yang luas dan alat yang banyak sehingga enggan untuk melakukannya (Wardianti \& Krisnawati, 2020). Dengan demikian perlu adanya suatu penanganan yang baik dalam pengelolaan sampah.

Penanganan sampah sendiri sebaiknya tidak dibebankan kepada pihak tertentu saja seperti

Volume 2, Number 2, Juli 2021 | 217 
pemerintah dan aparat kebersihan, namun dengan adanya suatu sosialisasi tentang sampah bisa menumbuhkan kesadaran dan kepedulian bahwa permasalahan sampah dapat dikurangi mulai dari rumah tangga. Penanganan sampah yang berbasis kemandirian memang perlu dilakukan, dengan tahapan pengumpulan hingga pemrosesan akhir (Mayasari, 2021). Salah satu cara yang dapat digunakan dan paling mudah untuk menjadi jalan keluar permasalahan itu ialah metode pengomposan bahan sampah organik terutama pada tingkat rumah tangga. Hal ini diperjelas dalam Suhastyo (2017), metode pengomposan dapat meningkatkan pengetahuan dan memberikan manfaat bagi warga desa. Salah satu metode pembuatan kompos sederhana, praktis, dan dapat diterapkan dalam skala rumah tangga ialah pengomposan dengan menggunakan bantuan komposter sederhana yang biasanya dapat dibuat dari timba-timba bekas. Selain sederhana dan relatif murah, metode pengomposan ini juga tepat untuk diaplikasikan dalam skala rumah tangga karena tidak membutuhkan lahan yang luas, dapat dipindah-pindah, serta tidak berbau.

Bahan untuk pembuatan kompos sangatlah mudah diperoleh karena ketersediaannya di sekitar dan cara membuatnya pun sangat mudah bagi semua kalangan masyarakat. Akan tetapi, pengetahaun dan keterampilan pembuatannya yang memang masih kurang, sehingga masyarakat enggan membuatnya. Maka dari itu, sangat diperlukan berupa sosialisasi dan pelatihan pemanfaatan limbah organik rumah tangga menjadi pupuk kompos.

\section{Metode}

Metode yang dilakukan pada kegiatan ini terbagi menjadi beberapa tahap sebagai berikut.

\section{Tahap Persiapan}

Pada tahapan ini dilakukan beberapa hal, dimulai dari menjalin kerjasama dengan warga dan perangkat desa hingga penyusunan jadwal pelatihan.

a. Menjalin kerjasama dengan perangkat desa. Dalam persiapan ini dilakukan permintaan izin kepada perangkat desa sekitar agar selama pelatihan berlangsung mendapat dukungan dari para perangkat sehingga kegiatan berjalan lancar.

b. Menjalin kerjasama dengan warga desa. Warga desa disini ialah sasaran dari kegiatan ini. Warga desa yang menjadi sasaran utama meliputi kelompok tani hingga karang taruna. Kerjasama ini mutlak diperlukan agar pelaksanaan kegiatan dapat terlaksana dengan baik.

c. Merencanakan kegiatan. Pada tahapan ini tim KKN pulang kampung merencanakan kegiatan pelatihan pemanfaatan sampah organik sebagai pupuk kompos. Pelatihan ini dikemas semenarik dan sesederhana mungkin agar warga dapat memahami dengan baik. 
d. Menyiapkan alat dan bahan serta pelatihan internal tim KKN pulang kampung. Pada tahapan ini tim KKN pulang kampung menyiapkan alat maupun bahan yang nantinya digunakan dalam kegiatan pelatihan tersebut. Selain itu, juga melakukan pembuatan contoh pupuk hasil pengomposan sampah.

e. Menyusun jadwal. Pada tahapan ini jadwal disusun sedemikian rupa agar tidak kegiatan tidak terbentur dengan aktivitas harian warga desa dengan tujuan target dapat tercapai dengan baik.

\section{Tahap Pelaksanaan}

Tahap pelaksanaan yang dilakukan adalah sebagi berikut.

a. Sosialisasi yang dilakukan kepada masyarakat mengenai materi limbah organik rumah tangga dan pengolahannya, kandungan pupuk kompos, dan manfaat pupuk kompos bagi tanaman.

b. Pelatihan yang dilakukan oleh Tim KKN Pulang Kampung Universitas Negeri Malang kepada masyarakat Desa Tamansuruh. Pelatihan dilakukan mulai dari mempersiapkan alat dan bahan yag digunakan untuk mengolah sampah organik menjadi pupuk kompos.

3. Tahap Evaluasi

Evaluasi yang dilakukan oleh Tim KKN Pulang Kampung berupa keberlanjutan program di lapangan. Diharapkan bisa dilakukan setiap sebulan sekali setelah kegiatan selesai dilaksanakan sampai mitra dapat menjalankan kegiatan dengan baik tanpa pendampingan.

\section{HasildanDiskusi}

\section{Analisis Desa Tamansuruh, Kecamatan Glagah, Kabupaten Banyuwangi}

Desa Tamansuruh merupakan daerah dengan mayoritas penduduknya memiliki mata pencaharaian sebagai petani baik petani padi maupun petani sayur. Hasil dari pertanian tersebut sebagian dipasarkan dan sebagaian dikonsumsi pribadi. Dengan adanya produksi pertanian yang berlimpah, mengakibatkan jumlah limbahnya pun meningkat juga. Terlebih lagi adanya limbah rumah tangga yang belum dikelola dengan tepat bahkan dibuang begitu saja dan dicampur dengan limbah anorganik seperti plastik. Meskipun limbah organik seperti sayuran ini dapat terurai dan tidak membuat kerusakan lingkungan, namun tetap saja limbah organik tersebut dapat mengurangi keestetikaan dan menimbulkan bau yang kurang sedap. Berdasarkan hasil pengamatan tim KKN Pulang Kampung UM 2021, hampir seluruh dusun yang berada di Desa Tamansuruh terdapat banyak limbah rumah tangga yang tidak digunakan dan dibuang sembarangan. Dari permasalahan tersebut, tim membentuk program kerja yang sejalan dengan kondisi di Desa Tamansuruh yaitu dengan memberikan sosialisasi 
GANDRUNG: Jurnal Pengabdian Kepada Masyarakat ISSN: 2721-6136 (Online)

dan pelatihan mengenai pemanfaatan sampah organik rumah tangga menjadi pupuk kompos kepada masyarakat desa khususnya dengan melibatkan kelompok tani. Hal ini bertujuan agar hal yang disampaikan menjadi lebih efektif dan efisien sehingga hasil dari program tersebut dapat diimplementasikan secara langsung oleh warga desa.

\section{Pelaksanaan Sosialisasi dan Pelatihan}

1. Tahap Persiapan

a. Persiapan Alat dan Bahan

1) Pembuatan Komposter

Pada tahap ini yang dilakukan terlebih dahulu ialah membuat komposter dengan langkah seperti berikut.

Alat:

$\begin{array}{ll}\text { - } & \text { Solder } \\ \text { - } & \text { Pisau } \\ \text { - } & \text { Gergaji }\end{array}$

Bahan:

- $\quad$ Timba berbentuk tabung

- Paralon

- $\quad$ Lem paralon

- Kran

- $\quad$ Plastik berkat
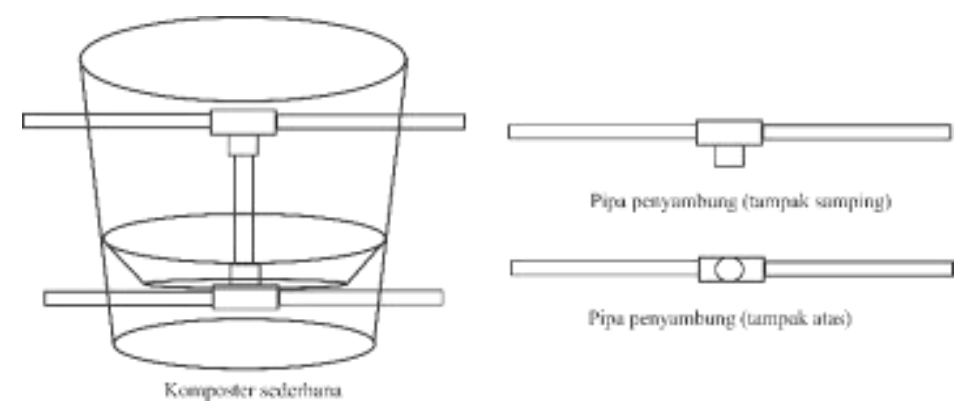

Gambar 1. Desain Komposter Sederhana

Cara Pembuatan:

Beberapa langkah dalam pembuatan komposter yang dilakukan ialah sebagai berikut.

a. Siapkan alat dan bahan untuk membuat komposter 
b. Lubangi bagian bawah timba seukuran kran dengan menggunakan solder

c. Pasang kran pada lubang yang telah dibuat

d. Lubangi bagian samping-samping timba seukuran paralon

e. Potong paralon dengan panjang $1 / 2$ dari diameter timba

f. Pasang pipa-pipa penyangga pada bagian bawah timba

g. Hubungkan keranjang ke sistem pipa bagian bawah timba guna memisahkan pupuk padat dan cair yang dihasilkan

h. Pasang pipa dan sambungan $\mathrm{T}$ ke arah vertikal

i. Pasang pipa kecil sesuai dengan desain komposter yang ada pada gambar.

2) Pembuatan Pupuk Kompos

Pada tahap persiapan ini dilakukan dengan mengumpulkan sampah organik dari sayursayuran dan dedaunan kering di berbagai dusun di Desa Tamansuruh serta alat dan bahan lainnya. Adapun alat dan bahan yang digunakan adalah sebagai berikut.

Alat:

a. Pisau atau gunting

Digunakan untuk memotong sayuran dan dedaunan kering menjadi lebih kecil agar mempercepat proses penguraian oleh bakteri EM4

b. Komposter

Tempat pembuatan pupuk

c. Semprotan

Tempat pembuatan cairan/starter

Bahan:

a. Air

b. EM4

c. Gula merah/tetes tebu

d. Dedaunan kering

e. Limbah organik rumah tangga

b. Persiapan Tempat dan Koordinasi dengan Warga Desa

Program kegiatan dilaksanakan di Halaman Rumah Ketua Kelompok Tani Dusun Mondoluko, Desa Tamansuruh, Kecamatan Glagah, Kabupaten Banyuwangi. Koordinasi dilakukan tim KKN dengan salah satu anggota kelompok tani mengenai jadwal dan kehadiran peserta. 
GANDRUNG: Jurnal Pengabdian Kepada Masyarakat ISSN: 2721-6136 (Online)

\section{Tahap Pelaksanaan}

Kegiatan sosialisasi dan pelatihan ini dilakukan pada tanggal 20 Juni 2021 di Halaman Rumah Ketua Kelompok Tani Dusun Mondoluko. Kegiatan dimulai dari jam 08.00 dengan melakukan persiapan di lokasi kegiatan yang dilangsungkan. Kegiatan pelatihan dihadiri oleh 15 warga Desa Tamansuruh yang diawali dengan menyanyikan lagu Indonesia Raya dan dilanjutkan dengan pemberian materi. Materi yang disampaikan oleh mahasiswa KKN kepada peserta ialah terkait dengan pengertian sampah, jenis-jenis sampah, serta cara pengolahannya.

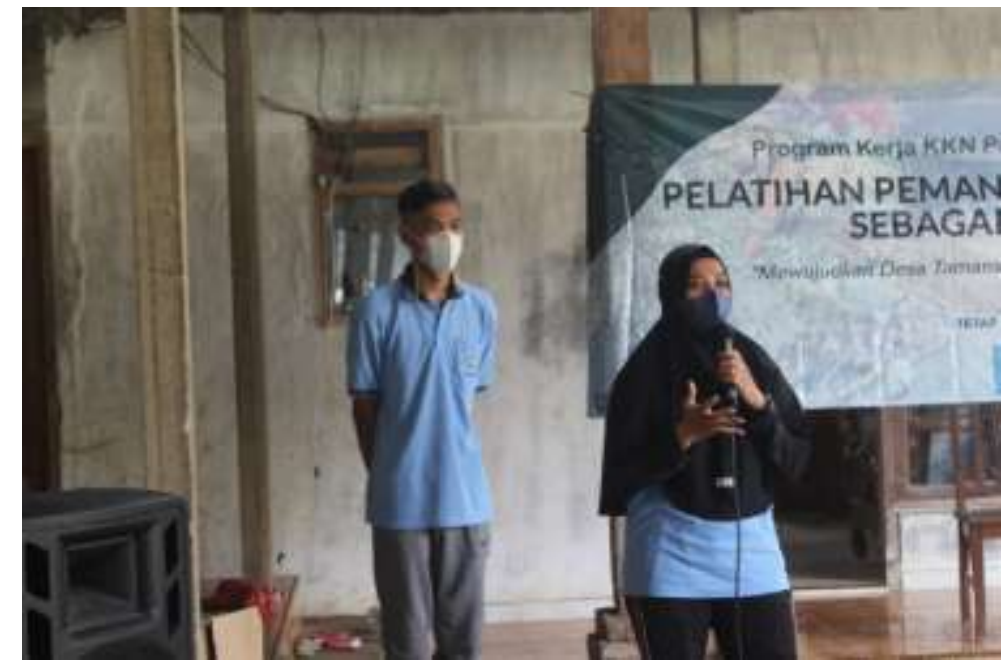

Gambar 2. Penyampaian Materi oleh Tim KKN

Setelah memperoleh materi, para peserta diberi pelatihan berupa pemanfaatan sampah organik rumah tangga menjadi pupuk kompos. Pada acara ini peserta diberi kesempatan langsung untuk mempraktikan cara pembuatan pupuk kompos berbantuan komposter yang telah dibuat pada tahap persiapan. Praktik dipandu dan didampingi oleh para mahasiswa KKN selama pengerjaannya. Adapun langkah-langkah dalam pembuatan pupuk kompos adalah sebagai berikut.

1. Siapkan komposter yang telah dibuat

2. Campurkan EM4 dan gula merah/tetes tebu ke dalam penyemprot

3. Tambahkan air secukupnya dan kocok hingga rata

4. Masukkan limbah organik rumah tangga dengan ketebalan $5 \mathrm{~cm}$

5. Campurkan dedaunan kering secukupnya

6. Semprot secara merata dengan menggunakan cairan/starter dari campuran EM4, gula merah/tetes tebu dan air 
GANDRUNG: Jurnal Pengabdian Kepada Masyarakat ISSN: 2721-6136 (Online)

7. Masukkan lagi limbah organik rumah tangga dan dedaunan kering, kemudian semprotkan untuk lapisan berikutnya. Langkah ini bisa dilakukan berkali-kali sesuai kebutuhan

8. Tutup komposter dan diamkan selama 4-6 minggu

9. Bila sudah jadi, pupuk dapat diambil dengan 2 cara, yaitu:

a. Untuk pupuk organik cair dapat diambil menggunakan kran

b. Untuk pupuk organik padat dapat diambil pada komposternya

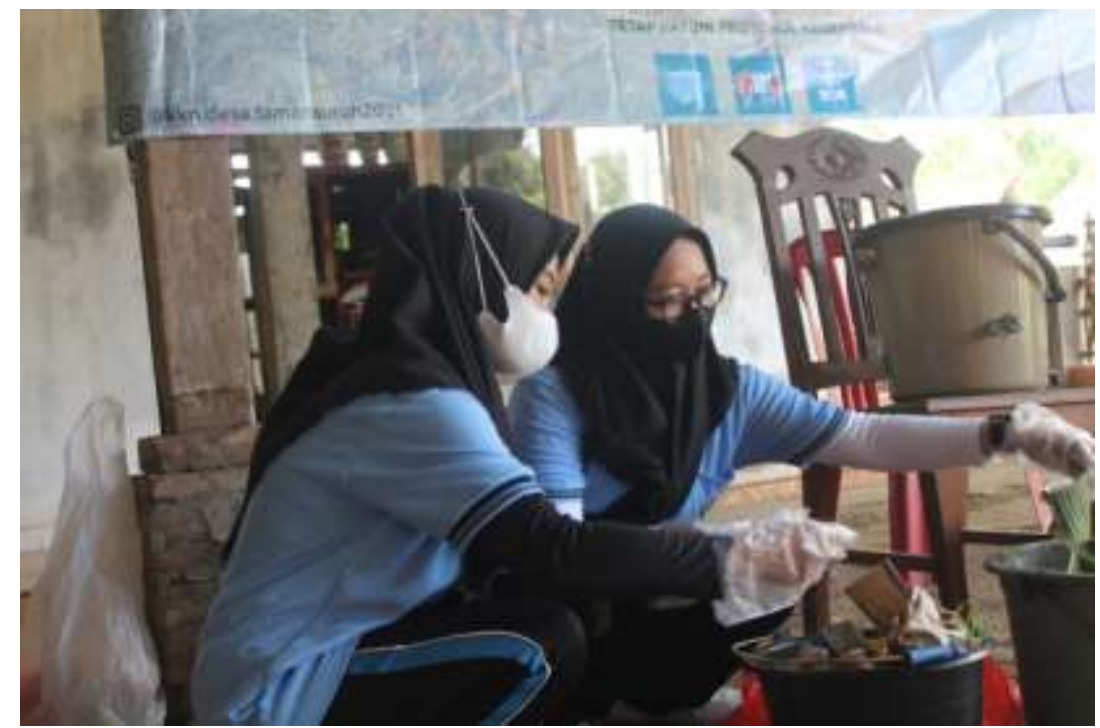

Gambar 3. Praktik Pembuatan Pupuk Kompos Bersama Warga

Kegiatan ini ditutup dengan sesi foto bersama dan serah terima pupuk beserta komposternya. Kegiatan pelatihan seperti yang telah dilakukan tim KKN diharapkan dapat meningkatkan pengetahuan dan keterampilan warga. Hal ini sesuai dengan pengabdian yang dilakukan oleh Suhastyo (2017), dimana pelatihan pembuatan pupuk kompos pada masyarakat memberikan hasil berupa peningkatan pengetahuan tentang manfaat limbah organik sebagai bahan baku pembuatan pupuk kompos, Sehingga diharapkan kedepannya warga Desa Tamansuruh bisa membuat pupuk kompos dari bahan organik sekitar mereka. 
GANDRUNG: Jurnal Pengabdian Kepada Masyarakat ISSN: 2721-6136 (Online)

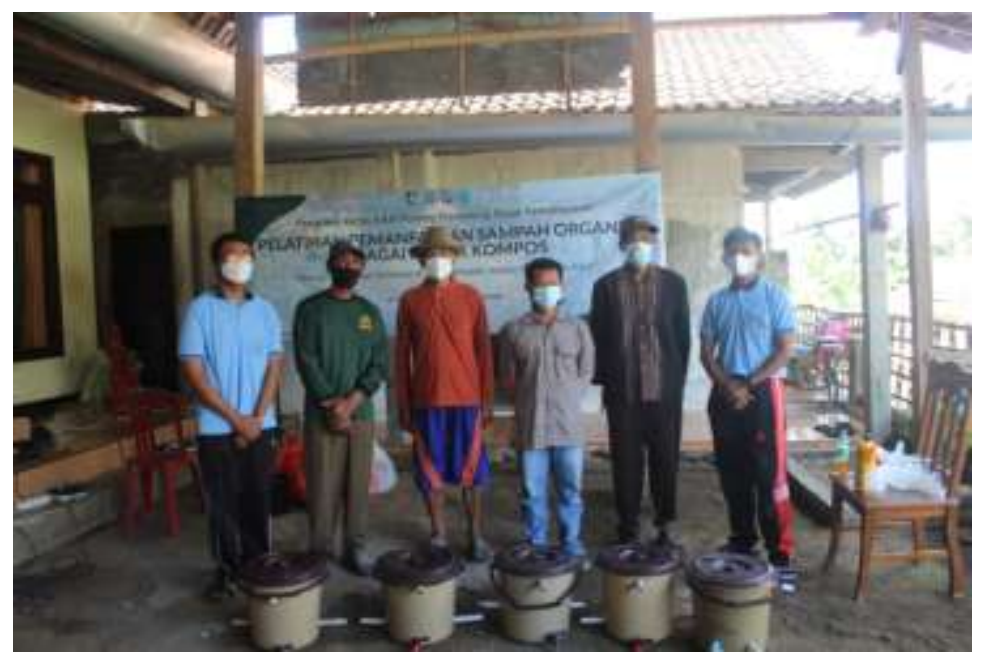

Gambar 4. Foto Bersama Warga dan Serah-Terima Alat Komposter

\section{Tahap evaluasi}

Tahap ini dilakukan pasca pelaksanaan dengan warga sekitar. Hal ini bertujuan untuk menyusun program keberlanjutan dari pelatihan tersebut. Berdasarkan kesepakatan dengan warga, bahwa akan dilakukan kunjungan monitoring setiap sebulan sekali. Selain itu, dilakukan juga rencana pengomposan dari limbah kotoran hewan yang juga melimpah di Desa Tamansuruh.

\section{Kesimpulan}

Berdasarkan uraian yang telah dijelaskan di atas maka dapat disimpulkan bahwa pengabdian masyarakat melalui program kerja KKN pulang kampung Universitas Negeri Malang 2021 berupa pelatihan pemanfaatan limbah organik rumah tangga menjadi pupuk kompos di Desa Tamansuruh telah berjalan dengan baik dan lancar. Program pelatihan ini dilakukan dengan cara memanfaatkan kembali limbah rumah tangga menjadi pupuk kompos yang kedepannya akan bernilai ekonomis dan dapat membantu menyuburkan tanah masyarakat Desa Tamansuruh yang mayoritas sebagai petani, serta dapat mengurangi sampah.

\section{Daftar Referensi}

Hadiwiyono, S. (1983). Penanganan dan Pemanfaatan Sampah. Jakarta: Yayasan Idayu.

Mayasari, D. A. (2021). Atasi Limbah Organik Melalui Pelatihan Pembuatan Pupuk Kompos Metode Keranjang Takakura Kepada Kelompok Dawis Cempaka Semarang. Abdimasku: Jurnal Pengabdian Masyarakat, 4(1), 49. https://doi.org/10.33633/ja.v4i1.145

Nur, T., Noor, A. R., \& Elma, M. (2018). Pembuatan Pupuk Organik Cair dari Sampah Organik Rumah Tangga dengan Bioaktivator EM4 (Effective Microorganisms). Konversi, 5(2), 5. 
GANDRUNG: Jurnal Pengabdian Kepada Masyarakat ISSN: 2721-6136 (Online)

https://doi.org/10.20527/k.v5i2.4766

Suhastyo, A. A. (2017). Pemberdayaan Masyarakat Melalui Pelatihan Pembuatan Pupuk Kompos.

JPPM: Jurnal Pengabdian Dan Pemberdayaan Masyarakat, 1(2), 63. https://doi.org/10.30595/jppm.v1i2.1425

Wardianti, Y., \& Krisnawati, Y. (2020). Pelatihan Pembuatan Kompos dari Sampah Organik Rumahtangga dengan Metode Takakura. Jurnal Cemerlang: Pengabdian Pada Masyarakat, 3(1), 1-11. 